\title{
Mind and Body in Mulla Sadra's Philosophy: A Psychological Relationship
}

\author{
Hossien Kohandel ${ }^{1}$
}

\section{ABSTRACT}

Mind body problem is the old philosophical debate many philosophers in all ages have engaged to solve the problem. Despite the efforts have been done by many philosophers of mind but still they are not able to provide a reasonable explanation of the problem, however, Islamic philosophers before MullaSadra also could not solve this problem. But MullaSadra introduced one new philosophical principle, such as principality of existence, intensity of being and substance in motion that succeeded to justify mind-body problem. This paper deals with the historical background of this issue and then goes through the psychological idea of MullaSadra on the relationship between mind and body.

Keywords: Mind-Body Problem, Mulla Sadra, Psychological Relationship.

Greek and Muslim philosophers discussed the question of the nature of soul and its relation with body. Before we come to discuss the views of Mulla Sadra on this issue it may be related to briefly introduce the ideas of two great philosophers, Aristotle and Plato. According to Plato, soul is a simple substance that is unlimited and generates all things and, while bodies it is immortal. Plato also believed but the soul and body are distinct from each other and this made his position dualistic in an ordinary senses. The soul is known as a simple substance but body is compounded or composite. The body consists of four elements of fire, water, earth, and air but soul is indivisible. The soul, more ever is of three kinds namely spirit, appetite, and intellect. Intellect is close to soul and appetite is close to body. When Plato spoke about the intellect or wisdom, he took wisdom to mean remembering rather than learning. Wisdom was exact opposite of ignorance and as such was closed to the intellect of soul. The idea of Aristotle about soul on the other hand is based on the concept of form which can be known as soul of body. According to him Soul is the perfection position for natural body. Soul and body are related to each other.

\footnotetext{
${ }^{1} \mathrm{Ph} . \mathrm{D}$ student of Philosophy, Department of Philosophy, Aligarh Muslim University, India.
} 
Soul is the form of body and body is the matter of soul. Soul is also the function of body. It was like the knife and its function of slicing something. The knife in the case was the matter and the function of slicing its form. Aristotle opposes the idea of Plato who that the soul and body can be separated from each other. According to Aristotle, soul is the emulative actions of body and soul cannot be separate from body. The soul also represented actuality while matter was potentiality. Potentiality meant matter which has not yet become actuality. Actuality was the form of matter. There could not be separation between from and matter just as the wax could not be separated from the impression imprinted in it. Aristotle thus rejects Plato'stheory of dualism. He believed that body and soul are made at the same time and there is no priority of one over the others. MullaSadra's position is close to the above idea of Aristotle. But Aristotle doesn't believe in the eternality and immortality of soul. Since soul is not able to exist without body. There is no other world and there is no life after death. But Mulla Sadra and Avicenna rejected this idea while accepting the co-existence of soul and body as held by Aristotle. Avicenna says that the intellectual part of soul will not die after body's death. Sadra held the same view of the immortality of soul following the doctrine of Quran. Another philosopher who is concerned with this subject is Plotinus who approached it from perspective of mysticism. He says that soul is sent from a spiritual realm to body. Body is the recipient and confinement of soul in this world. In opposition of Aristotle, he believed soul and body are two different beings that connect be integrated into a whole.(Fazlul Rahman, 1975).

Plotinus divided souls to in three kinds: the intellectual soul, the animal, and the plant soul. Plotinus accepted the existence of souls in world and he recognized them as individual souls that admit modifications. The Muslim philosophers like Ibn Sina and MullaSadra who followed Plotinus held more or less similar views. Avicenna being also the follower of Aristotle prefers to call soul as perfection that takes into account both the material and spiritual view. It is perfection because matter doesn't have the ability to become perfect without soul. The concept of perfection is preferred over potentiality for the definition of soul, because potentiality has two powers of perception and motivation that are in the category of passivity and actuality but such a concept cannot define soul perfectly. Perfection itself is of two types. First type of perfection is where the soul is integrated with its matter and show latter in its completed formatter. It is like in the care of bed which made by wood. The wood is the matter of which the bed is the completed form. The second type of perfection is seen for example in the case of knife slicing on object. in this case; knife is the matter which slicing is the form and the function. The soul represents the 
first kind of perfection in regard to soul because the soul is not a function of the body but is its perfected state and integrated with it. Mulla Sadra says:

"The soul is the first entelechy for natural body, but not for all natural bodies since the soul is not entelechy for fire or land, rather in the natural world it is first entelechy for natural body that can make second entelechies via some tools which help it to do life actions, like feeling and volitional motion"(Mullà Sadrà, Asfar, 1981, v, 8, p. 17).

\section{Mind-body relationship in philosophy of Mulla Sadra}

Since Mulla Sadra believes motion in substance, he talks of movement of soul starting from material soul to eternal soul. The body gives from childhood to become old but the truth and reality of a person remain stable. Man has awareness of his being and such awareness shows the separation of soul from matter which is not eternal. Mullasadra is in the category of philosophers who believes the spirituality and eternality of soul. Soul remains after death and the destinations of soul and body are different. But when the soul is still in the generative stage (Takvin)it needs matter and as long as it needs matter its destination same as matter but when soul get free of matter, it finds its own destination which is different from matter. Thus the motion which is in substance is a process of growing from lower stages to the stage of perfection. Soul and body are created at the same time and at that time they are of same level. But after some time soul develop itself toward intellect and then it becomes simple and eternal.

Mulla Sadra have two main explanation about soul that as follow;

"I call every active faculty (quwwafā'iliyya) which produces traces not in a univocal (or: one and the same) way "the soul". This expression names this faculty not in the respect of its simple (non-compound) essence, but in the aspect of its being the principle (or: source) of suchlike acts; i.e., acts that occur not in a univocal manner-J.E” (MullàSadrà, Asfar, 1981, v, 8, p. 5).

The second one also defines the soul in respect to its actions, but in this case-by stating that they are carried out through one or more intermediaries, not directly:"We treat as the soul the faculty of the natural body whose rank is such that it performs its acts by employing (literally: "by making serve to itself”) (istikhdām) other faculties [that are] under it" (MullàSadrà, Asfar, 1981, v, 8, p. 17).

This second definition cannot be properly understood if considered without connection with Sadrā's famous principle "the soul is all faculties" (al-nafskull al-quwa), which (principle) is a branch and an instance of the more general principle, mentioned above, namely "a thing 
which is simple is all things" (basìt al-haqīqakull al-ashyā'), which is to be understood to the effect that a more intense degree of existence contains in itself all weaker ones.

"As the soul grows up in its existence, body will be more delicate and more limpid and its connection with the soul will become more intensive. Then the unity of the two will be more powerful so that it can reach the degree of intellectual existence which means being a single entity with no distinction"(Tūsī and qutb al-din Rāzī,1996).As to the question whether soul is existed from eternality or it originated in time, different Islamic philosophers gave different answers some of them believed soul to be originated in time while others are had the contrary idea. Mulla Sadra himself believed that, the soul originated in time and won created along with matter. Before him Avicenna and Al-Ghazali also believed in the originated soul. The critical question was what wins the time of creation of soul? Some philosophers believed that the soul is created before the creation of body while others said it is created after body. But Mulla Sadra says that the soul is created simultaneously with the creation of body. The soul of man didn't exist before body but come into existence alongside the body and is the state of any action that it reaches to perfection and become simple with the help of substance in motion. In time with other Greek and Muslim thinkers, Sadra also spoke of three types of soul. i.e. the plant soul, the animal soul and human soul. The plant soul is related to liver, animal soul is related to heart and the soul of man to brain (Intellect). These three types of soul are together in creation. The plant soul is created first and next the animal soul and finally the human soul that is highest is created. There is no any life for the souls of plants and animals after death. When the bodies of plants and animals are annihilated, their souls are destroyed, too. But the soul of man remains after death because it is connected to intellect which is eternal, (Mosleh, Javad,1973).

\section{The classification of soul in philosophy of Mulla Sadra is as follow;}

Further, Mulla Sadra says; 1. The soul of plant consists of faculty of feeding, growing and reproduction. 2. The soul of animal consists of two parts of motive power, perceptual faculty. 3. The soul of human being is also divided into two parts of theoretical faculty and practical faculty or practical intellect. Theoretical faculty of intellect has four parts of material intellect, habitual intellect, actual intellect, and acquired intellect. Against the general view that the soul is spiritual and eternal and mortality belongs to the realm of matter. Mulla Sadra says that, it is not reasonable to say that soul is immaterial and completely different from matter that the soul as intellect in itself is added to a body. Basically, indeed, there is no difference between soul and body. Originally, the soul wasn't immaterial but as substance in motion, it moves itself to the 
state of perfection. It is a contradiction to think that man can be made from a corporeal matter with an intellectual form added to it unless some intermediary would be there to connect the two. The humans have two parts of body and soul and these represent the existence of him at two different levels. But, ultimately they are one entity which is both changeable and stable. Mulla Sadra says:

So we say-and from God is the succor-that their saying: "the soul is in movement because it is the first mover" is a sound view which has been demonstrated. From that [view] it does not entail that the soul is one of the bodies. As for its movements by itself [or by its essence] according to the intensity, its explanation [by us] has been established by the demonstration. It has already been mentioned clearly and in allusion that it has continuous substantial developments and [continuous] essential metamorphosis from the level of sensation to the level of intellection. At times it unites with the [external] sense [organ], and that is at the beginning of its creation and generation; [at times] it advances and reaches the level of imagination, then it unites with the faculty of imagination if it reaches a station when the intelligible forms are present before it and it witnesses [them], then it becomes an immaterial intellect, purified in its essence from the bodies and corporeality, (MullàSadrà, al-Asfàr, 1981, v. 8 , p. 244-245). The connection of soul and body are necessary and this soul necessary related to corporeal body so the truth of soul is related to body, it is not accidental to the body,(Ibid, vol. 8, p. 12.).

The soul and body are not independent of each other. They are interdependent and the relations between them are essential. They are one reality or one being which is seen from two different perspectives. According to Mulla Sadra:

The human soul exists before the creation of body, without needing the reincarnation (tanāsokh) or the eternality (qidam) of the soul-which Plato believed in-...and there is no problem with the division of the united soul into multiple souls or to say that the soul has been doing nothing before the creation of body...as if the existence of the spirits (arwāh) before bodies is one of the requisites of the Imamite Shiee as. Āhanī, G.H. (1962).Mulla Sadar separated soul from the realm of spirit although according to Quran, soul is spirit which is created before the matter and body. According to Mulla Sadra, the soul of man consists of three kinds; material, ideal and intellectual. The material soul is pertains to potential state like seed before growing into a tree. The ideal soul of man is also potentiality but in the animal mode. The intellectual soul of man represents him complete actuality where the intellectual human soul stays with body and has 


\section{Mind and Body in MullaSadra's Philosophy: A Psychological Relationship}

movement. But after getting free of body it causes to have any motion and becomes stable. The consciousness or awareness which humans have is because of this intellectual soul. In the selfawareness knowledge is the same as knower and when we receive knowledge, the substance of soul starts moving. While the soul is in body, it has such a motion but as said, after getting free of body, it doesn't have motion.

"The five perceived ones (i.e., things perceived by five external faculties of the soul J.E.)...Are hidden (ghaybiyya) (i.e., not perceived externally-J.E.) luminous likenesses that exist in another world, not the qualities that are called "the sensible ones" (mahsūsāt) [which are not perceived] otherwise than accidentally, and they (the qualities essentially perceived by the soulJ.E.). Are psychic qualities (kayfiyyātnafsāniyya), and if you want to learn the truth, [you must know that] these faculties do not subsist by the bodily parts, but rather the bodily parts subsist by their command, because the demonstration shows unshakably that if something inheres in some other thing and the existence of this inherent thing in itself is its very existence in its locus, [then] it is impossible that it would exist in one world and its locus-in another. Hence, the inherent thing and that in which it inheres [both] are in one [and the same] world, and the perceiver and the perceived are of one kind". (MULLA SADRA, 1962).Mulla Sadra believed in the materiality of soul. He brought some arguments in Asfar to prove materiality of soul. He said there is movement in material or external world and in soul, too. This argument obviously follows the theory of substance in motion which is an exclusive theory of Mulla Sadra. As said before, soul can find its own way and get free of material body with the help of motion which is essential in substance. The soul has motion too because soul will reach perfection with the help of body. According to him: He says about materiality or immateriality of soul as follow:

"In truth, the human soul is corporeal in existence and disposal, and spiritual in subsistence and intellection. Hence, its disposal in the body is corporeal, whereas its intellection of its essence and of the essence of its maker is spiritual. As for the immaterial intellects, they are both spiritual in essence and in act; the natures are both corporeal in essence and in act. So each of those [two] substance has a known station, which is not the case with human soul. That is why we judge its development at different levels. Because its disposal in the body is not like the disposal of the immaterial intellect in the body, for by its essence it is the direct agent of inducing particular movement and particular perceptions in the way of passivity and seeking for perfection, and not in the manner of emanating and originating [I.e., creating], (Mullà Sadrà, 1981, Al-Asfar, v. 8, p. 348).He says in another place: 
"You must know that the soul, which is the form of the human being, is corporeal by its[temporal] origination (jismāniyyat al-hudūth) and spiritual by its subsistence (rūhāniyyatalbaqā'), because, as it was established earlier, the passive intellect is the last of the corporeal meanings and the first of the spiritual ones. The human being is a road stretched between the two worlds, and he is simple by his spirit, but compound by his body. The nature of his body is the purest of the earthly natures, and his soul is the first of the levels of the noble souls. He has a rank that permits him to assume an angelic form. When he turns away from what befits him best, [then] he deserves that [to which he has turned himself] rather than ascent to the ranks of the noble ones. He takes off the human form, and the angelic form eludes him, and through his actions he assumes either devilish, or [predatory] beastly, or brutish form, and remains in the flame of fires, without ascending to the degrees of gardens"(Mulla Sadra, (1987), Al-Shavahid Al- Rububiyyah, p. 311).

In conclusion, the philosophers who followed of Aristotle such Avicenna, believed that, soul is stable and there is no motion in it but Mulla Sadra believed that since soul needs body, it has motion though when it gets free of body and reaches perfection, it becomes stable and without motion. In other words Mulla Sadra accepts the motion of soul in this world and also accepts the stability of soul after life of this world. In Asfar he says:"The soul is created by time at the same time that perfect bodies are created, since the vegetal soul is tempered to body and is the form of body. Therefore origination of the foetus body is for the soul that is the form of body."(Al-Asfar, vol. 8, p.330).

According to him soul is one part of material body and it is the form of body at the level of plant soul and he develops to become rational soul that is free of matter. MullaSadra tries to justify his intuition that the soul did not exist before body and that it existed only with body at the same time. He wrote:"Remember the story of the human soul's fall from the sacred world to this world, the location of corporeal nature which is like the cradle and the homeland and the mother of the animal soul. This has been stated in the prophetse words and the great sages and holy men's allusions, (Asfar, Vol. 8, p. 355).In this context he also quoted the following verse from Quran: "When the God drew forth from the children of Adam- from their loins-their descendants and made them testify concerning themselves (saying) am I not your lord (who cherishes and sustain you)? They said; yes we do testify (this lest yea should say on the day of judgment of this we were never mindful" (QURAN, Al- Araf, 7, verse, 172). This verse of Quran makes clear that man existed before he comes to his body. The soul didn't exist before body. If 


\section{Mind and Body in MullaSadra's Philosophy: A Psychological Relationship}

the soul was created before material world then the separation of soul and body should be there but he didn't believe this Platonic idea because if the soul is something apart from body, then how could the soul renew itself to perfection. Thus if we accept the progress of the soul to perfection then we have to accept the creation of it at the time of body; otherwise there will be contradiction in it,(Sadra, Al-Asfar, vol. 8, p. 330). The Islamic philosophers like Avicenna also believed that there is only one soul for one man and it is the origin of action. Mulla Sadra on the other hand says that, soul is all of the powers in its unity. All the actions which are caused by a soul are done in itself. According to mulla sadra that Soul or self is simple intellectual existence which is known as one of the form in divine knowledge (Seyed Mohamad Khamenei, 2004); the important question here is if the soul is the intellectual form in divine love how can it connect to body? Before discussing this question, we must first clear the idea of Mulla Sadra about matter. According to him matter is the lowest level of existence and because of this low existence; it has low consciousness, too. We cannot say matter is nothing. Matter is potentiality ever striving to become the actual form. The relation between soul and body is the relation between form and matter. It means both of them need each other and such a dependency is necessary. The soul is not simple and eternal at first but it has ability to become immaterial and simple after getting perfection. Therefore Mulla Sadra says:

Body or matter is the lowest level and intellect is the highest level of existence. Body is in soul and soul is in intellect. It means the existence of man comprise of three steps: first the bodily existence, the second the soul with body and the third the intellectual being. As body and body with soul, human being has organic existence and is not stable but the intellectual is spiritual and stable."The carrier (or: subject) (hāmil) of all faculties of the human soul and its vicegerent is the vaporous animal spirit, which emanates from the pure and subtle part of the mixtures (ikhlāt) in the same way as the [bodily] members emanate from their (mixtures'-J.E.) impure and dense part, its (animal spirit's-J.E.) locus of origin being the conically shaped heart" (Sadr al-Dīn al-Shīrāzī, 1979).“These elements and pillars continue to mix perpetually, until finally [their mixing] results in[giving existence to (?)] the human body. The human body [, in turn,] continues to refine and unify itself, and to purify and to change itself, until this results in its [animal] spirit - the one which is a subtle body that emanates from the heart, from its left cavity. In respect to its purity and refinement, its light and luminosity, and its distance from the opposites (closeness to which causes corruption), this animal spirit resembles the body of the celestial sphere. Therefore it becomes the mirror for the rational soul, through which it perceives existence in its entirety" (Mulla Sadra, 1987. Al-Shavahid Al- Rububiyyah, p. 311). 


\section{CONCLUSION}

Psychosomatic is the idea that is common both in abnormal psychology and in medicine. It is also known as holistic view to the mind-body problem that is based on the some questions regarding to the etiology of disease. The point is that there are some diseases and mental disorder that is based on organic problem but these problems can be studied in psychological matter. But there are another problems like behavioral disorder and mental problems that we are able to find a perfect defined organic cause; such a problems like stress, and anxiety etc., have psychological causes. The above mentioned indicates to the intimate relationship between psycho and soma and form the basis for the psychosomatic or holistic viewpoint. Thus, it is the result that every disease, organic or mental, is the disease of the whole organism so we should not study organism as two entities that are separated from each other but they should be known as one unified. This psycho-somatic idea can be close to the theory of mind-body relation in philosophy of Mulla Sadra. He is concerning to the mind body problem that is based on his existential philosophy in which both mind and matter hold the intensity of existence. According to him mind and matter are not two strange things that are separated from each other but in intensity of being. Then both of them are different levels of human being. It means that mind and matter are same nature but only the intensity of being is there. There is no non-existence in the world. The higher in existential intensity affects the lower in existential intensity. The whole cosmos is connected, interactive and alive due to existence. However, Mulla Sadra has brought together medicine, philosophy, physics and spiritual science in his thought and created a new picture of highly connected and interactive universe.

\section{REFERENCE}

Āhanī, G.H. (1962).SH, p. 239). Dhurham chapter 5.

Fazlul Rahman. (1975). The Philosophy of MullaSadra, State University of New York Press, p. 247.

Mosleh, Javad. (1973). ravanshenasiesadrolmotahelin or elmonafs, published by university of Tehran, P.174).

MullàSadrà, (1981). al-Asfàr. al-Hikmat al-muta'àliyah fi al-asfàr al-arba'a, Beirut: DàrIhyà alTuràth al-Arabi).

MullaSadra, (1987). Al-Shavahid Al- Rububiyyah, Tehran,.

MULLA SADRA. (1962). Arshīyya, 236, translation and Edited by, Golam Hussein Āhanī, Isfahan: Shahriar Publications, SH. P. 236).

(QURAN, Al- Araf, 7, verse, 172).

Sadr al-Dīn al-Shīrāzī, (1979).al-Wāridāt al-qalbiyyafīma'rifat al-rubūbiyya, ed. A.Shafî‘ īhā, Tehrān: Iranian,Academy of Philosophy, 83-84).

Seyed Mohamad Khamenei, (2004). Al-Asfar, v 8, Tehran, entesharatsadra, p. 428.

Tūsī and qutb al-din Rāzī. (1996).Al-IshārātwalTanbīhāt, commentary of Tūsī and qutb al-din Rāzī. Isharat, v, 9, p. 112-113. Qom:Nashr Al-balāgha Publications. 